\title{
Rereading the National Library
}

\author{
CÉlia MARIA PoRTElla
}

HE CREATION of this bicentennial institution occurred in the context of the period of the Portuguese reign in the colony named Brazil.

( Therefore, its journey is an integral part of the history of our country.

On November 29, 1807, the Portuguese royal family left Lisbon pressed by the Napoleonic troops. The Portuguese Court moved to Brazil, bringing with it the collection of what would make up the National Library. The items were divided in three lots, the first of which, brought by D. João VI, arrived in Rio de Janeiro on March 7, 1808; the second, packed in "two hundred and thirty crates" arrived in mid-1810 (Cunha, 1981); and the third, perhaps because the situation in Portugal had improved, was never shipped. They did not bring a single gift, or Crown jewel, but rather prized and appraised assets, which fetched good prices in the market at that time. So, a rather amusing anecdote is still heard to this date among the good-humored people of Rio de Janeiro: "Who bequeathed this collection to us? Was it the king of Portugal or Napoleon?" ask sarcastically the Portuguese- or French-mannered interpreters.

The fact is that the National Library, was originally established "in the houses of the Hospital of the Third Order of Carmel, on Direita Street [today Primeiro de Março], between Carmo Church and the Imperial Chapel [formerly Cathedral]" by royal decree of June 27, 1810, which was later revoked on the grounds of inadequate and insufficient physical space. As a result, part of the precious collection was eventually transferred to the so-called "catacombs", also known as basements, in the same building, deemed "a more appropriate and decent place to accommodate said library." The Library was officially established on the same date of the new decree: October 29, 1810. Its pilgrimage is search of a suitable address, always resulting from the limited facilities in which it was located, included also Passeio Street [August 5, 1858], which is currently home to the School of Music of the Federal University of Rio de Janeiro (UFRJ), until it was finally transferred to 219-39 Rio Branco Avenue, in Rio de Janeiro (RJ), which has been its permanent address since October 29, 1910. The building, one of the urban landmarks of city at the turn of the Twentieth Century, was started in 1905, on a plot of land obtained after the demolition of part of Morro do Castelo. It is part of the architectural ensemble remaining from the first generation of buildings on Central Avenue [today Rio Branco Av.]. In 1973, both the building as its gardens were listed by the Institute of Historical and 
Artistic Heritage (IPHAN), and the Library was definitely protected from new and pointless transfers.

The Royal Library -- which consisted of two: the Library of the King and that of the Infant's Estate, the latter being reserved for the use of princes (Annals of the National Library, 1883-1884) - was later renamed Imperial and Public Library [September 13, 1822] (Schwarcz, 2002, p.405), National Library of Rio de Janeiro [March 4, 1876] and finally simply National Library [1948] (Annals of the National Library, 1883-1884, p.568). It has grown incessantly, either through the acquisition of books and collections, subscriptions to foreign periodicals or the enforcement of the Legal Deposit Law [Decree of December 20, 1907], which sprouted from the charter of October 12, 1805 (ibid, p.18), whereby "of each and every edition published in Portugal, and later at the Royal Press of Rio de Janeiro, at least one copy should be 'offered' to the Library of the Court" (Carvalho, 1994, p.47). This was continued through Law No. 10994 of December 14, 2004, thus constantly expanding the collection of the institution, since it stipulates that a deposit must be made with the National Library (Biblioteca Nacional-BN) of a copy of every publication produced in the country by any means or process, in order to ensure the collection, custody and dissemination of the Brazilian intellectual production and the preservation and development of the National Memory Collection. It should be noted that Law No.12192 providing for the legal deposit of musical works with that institution as well, was enacted in January 2010.

The collection of the $\mathrm{BN}$ was also increased as a result of the enforcement of the Copyright Law [ No. 9610 of February 19, 1998], which governs the protection of intellectual property and provides, under article 19, that "for the safety of his/her rights, the author of an intellectual work may register it, according to its nature, with the $\mathrm{BN}$ " and, to that end, deposit an original of the work to be registered with the Archives of the Library, which then will have the custody of the authorship memory. The practice dates back to 1898, when the first copyright act, ${ }^{1}$ Law No. 4961 was enacted on August $1^{\text {st }}$. In operation since the nineteenth century, the Copyright Office (Escritório de Direitos Autorais EDA), linked to the National Library Foundation (Fundação Biblioteca Nacional-FBN), has accumulated an enormous collection of supporting documents related to the registration. The object of this process, the intellectual work, is preserved at the EDA, primarily on the basis of its legal value, making up the archives of the body/section conventionally named collection and kept in a facility which is physically and intellectually separated from the central unit, with more than 3,000 registrations each month.

The Royal Library was growing in both quantity and quality. ${ }^{2}$ The original collection consisted of the 60,000 items, including books, manuscripts, prints, maps, coins and medals from the Bookstore organized by D. José I to replace the Royal Library that had been destroyed by the fire caused by the earth- 
quake that struck Lisbon in 1755. That collection comprises incunabula, manuscripts, prints, maps, and medals. It was incremented by the Barbosa Machado, Conde da Barca or Araujense, de Angelis, Salvador de Mendonça, José Antonio Marques, Thereza Christina Maria, Wallenstein, Benedito Otoni, Casa dos Contos, Alexandre Rodrigues Ferreira, and Abraão Carvalho Collections.

Among the rarest and most valuable manuscripts of the National Library are the Evangeliário (Evangeliastary), Eleventh and Twelfth Centuries); Livros de Horas (Books of Hours), Fifteenth Century; Codices of the colonial administration; Map of the farthest corners of Brazil with the lands of the Spanish Crown in South America [1749]; original drawings of scientific expeditions to Brazil (sixteenth to nineteenth centuries); photographs donated by D. Pedro II; prints: the Bible of Mainz (1462), the first edition of Luís de Camões's The Lusiads (1572), Grammatica da Lingua Portuguesa com os Mandamentos da Santa Madre Igreja (Grammar of the Portuguese Language with the Commandments of Holy Mother Church; 1539), brochure by Luís Antônio Rosado da Cunha, considered the first work printed in Brazil [Rio de Janeiro: Segunda Officina de Antonio Isidoro da Fonseca, MDCCSLVII]; ${ }^{3}$ the original musical score of Carlos Gomes' O Guarani (The Guarani), 1870); musical scores by Mozart, Fosca, Mary Tudor, Salvador Rosa; engravings by Albrecht Dürer, Oswaldo Goeldi; and Giovanni Piranesi, among many others.

Beyond its precious collection of rare and beautiful works, the Royal Library is linked to the recognition of Brazil as an autonomous nation. Manuscripts and printed books and documents are now part of the collection of the National Library treasures.

It is appropriate to clarify that it was not simply a generous donation from the Portuguese Crown, but a costly acquisition for the young country (cf. Schwarcz, 2002, p.395-401; Carvalho, 1994, p.46, 51). Heated debates between publishers, booksellers, librarians, economists and authors about the fixed or free price of the book are common today. But at that time it was fixed without further debate or public consultation. As if that hadn't been enough, the country of origin promoted a curious cost reallocation, which consequently had un upward effect: "800 (eight hundred) contos, which at the time corresponded to 250,000 pounds or approximately 12.5 percent of the amount to be paid" for the items that "Portugal would be entitled to claim from Brazil." But that's water under the bridge.

Currently the National Library is officially considered by UNESCO the eighth largest in the world for its historical value and number of items. It houses the richest collection of books in Latin America, with more than nine million items. It is responsible for collecting, storing, preserving and disseminating bibliographic production in Brazil. Today it is an irreplaceable reference for professionals in the humanities, sciences, arts and for those conducting research on the construction of Brazil and on European projections in the New World. 
Thus, the search for possible solutions to the expansion - or extension - of the Library's facilities is still on. The renovation of the building located at 509, Rodrigues Alves Street, in the port area of the city of Rio de Janeiro, which started in 2007, is expected to be resumed in the current administration [2006 - ], with the support of Petrobras. A branch of the National Library Foundation since 1987, the building is being adapted to the needs for storing bibliographic material, for the establishment of the first Brazilian Hemerotheque, which is the appropriate place to store serial publications, i.e., national, regional and local newspapers, magazines, official publications, newsletters and yearbooks, currently estimated at 3.5 million items, which increase on a daily basis, thus making room for other publications in the large warehouses of the main office building on the Rio Branco Avenue. The organization of the newspapers started in 2009, with their transfer from the main office building [7th and 8th floors] to the new facility in a building built in 1946, which has a structure sized to store heavy material - $600 \mathrm{~kg} / \mathrm{m}^{2}$ - and a footprint of about $16,000 \mathrm{~m}^{2}$. Although the building is sufficient to meet the demands of the FBN, renovation works need to continue in order to adapt it to its new use, together with the rehabilitation of infrastructure to ensure its functionality.

By the early 1990s the FBN, in need of space to establish the then $\mathrm{Na}$ tional Book Department (Departamento Nacional do Livro - DNL), decided to transfer to the new building the entire collection of the so-called Parallel Collection [collection without technical processing], at the time housed on the ground floor of the main building. Also transferred was the collection of foreign periodicals, the collection of the former National Book Institute (Instituto Nacional do Livro - INL), the technical reserve [publications], the Theses Collection [with over 40,000 volumes] and the administrative archive of the Institution. When the new facility began to be occupied, the need emerged to resize the profile of that transfer. The project for the " $21^{\text {st }}$ Century Library" [1996-2002 administration], which depended upon sponsorships by and/or partnerships with the private sector, was then prepared. While resources were being sought to cover the high costs of the undertaking, minor repairs were made to adapt the facilities to the needs of the different collections.

The challenges have always been the same, among them the fear of fire and of loss or deterioration of the books. Neither the anxieties nor the representations are unique. No nation can be independent without a National Library that can quickly become a kind of mirror and showcase of its culture.

\section{Administrative background}

The first official regulation came out only in 1821 with the Statute of the Royal Library. With Brazil already independent, another regulation was approved, the Regulatory Articles for the Imperial Bylaws of the Imperial and Public Library, on September 13, 1824. A new Regulation for the National Library was defined in Decree No. 8835 of June 11, 1911, which provided for major 
administrative and cultural innovations, including those relating to the duties of the director and the establishment of the "Advisory Council, an ancillary body to the administration, which included all managers." The National Library was linked, initially, to the former Ministry of Interior and Justice, and then to the Ministry of Education and Public Health until 1953. With Law No 1920 of July 25, 1953 providing for the establishment of an autonomous Health Ministry, the former Ministry of Education and Public Health was renamed Ministry of Education and Culture (Ministério da Educação e Cultura- MEC).

It is appropriate here to distinguish between public library and national library.

The cultural context of the Middle Ages, when the largest number of libraries emerged, led them to be closed, since the people were not readers and the book was considered a treasure, an object to be preserved, protected. In Europe, when libraries came out of the monasteries, they were subjected to the kings. Consequently, our National Library was initially a library of kings, princes and noblemen. Under the influence of American culture, which identified the library as a need of the people, public libraries began to emerge. They were protected, free, and their regulations governed by the local power. ${ }^{4}$ This new interpretation of what a library would be -- for the people and therefore public -- was disseminated throughout the world, but the first public library was only established in Europe, more precisely in Belgium, in the mid-Nineteenth Century.

The concept of national library seems to have arisen or matured in France during the French Revolution. It was national because it housed the documentary memory of a country's culture. Today, a library is considered national because: it is the beneficiary of the Legal Deposit; it has a structured mechanism for the purchase of library materials abroad, in order to bring together a significant collection of foreign works, including books related or of interest to Brazil; it prepares and disseminates current Brazilian bibliography through the National Library portal (www.bn.br); and it is the national center for bibliographic exchange, both nationally and internationally. It is, in a broad sense and a higher level, a museum of the country's entire bibliographic and documentary production in various fields of knowledge throughout its history.

A National and Public Library, however, is not synonymous with popular. It should be used by a specialized audience, an elite of knowledge and culture. A National Library seeks through all available and updated means to put the collection at the disposal of researchers, either directly through handling works and documents, or consultation of microfilms and facsimile editions, in the case of materials fragilized by aging. In this case, the users are people who conduct online searches by visiting the National Library website and the so-called remote users, i.e., those who submit their inquiries to the Information Division (Divisão de Informação - DINF) by phone or mail.

To meet the purely public needs, the institution is linked to: the Euclides da Cunha Library (Biblioteca Euclides da Cunha - BEC) and the Demo Library 
of Brasília (Biblioteca Demonstrativa de Brasilia - BDB ). The history of the establishment of BEC [January 13, 1937] is closely linked to the administration of Minister Gustavo Capanema at the Ministry of Education and Public Health, and to the opening of its namesake building, since its construction project included plans for the establishment of a library, which it in fact has been housing since 1944. BEC offers free public access to reading, information and records of cultural and intellectual expression, by conducting activities of an informative, educational and cultural nature. The BDB, according to Eduardo Portella, "is an outpost of the National Library Foundation in the capital of the Republic, which has proved technically competent and displayed an impeccable spirit of public service". ${ }^{5}$ Officially opened in 1970 it aims, in addition to serving as a model for public libraries in the country, to provide the community of Brasília with the necessary conditions to conduct research, as well as reading, learning and leisure. The BDB not only lends books, but also functions as a cultural center by promoting concerts and contests, and thus attracting more people.

But let us go back to the period when the National Library was under the administrative supervision of the Secretariat of Cultural Affairs (Secretaria de Assuntos Culturais - SEAC) [former Department of Cultural Affairs (Departamento de Assuntos Culturais - DAC)] of MEC, and its institutional operation was hindered due to lack of autonomy. In 1981 the bicentennial institution was transferred to indirect administration, as part of the National Pro-Memory Foundation, until 1984 when it became, along with the National Book Institute, the National Pro-Reading Foundation.

As a result of the State administrative reform in 1990, the National ProReading Foundation and the National Book Foundation were replaced by the National Library Foundation (FBN) by Law No. 8.209 of April 12. The National Library, by Decree No. 99603 of October 13, 1990, was made a Foundation under public law, linked to the Ministry of Culture, thus expanding its area of action, as it began to operate in the key areas of books, reading and libraries.

The new functions absorbed by the National Library led to other operational and human demands, promoting a broad conceptual reassessment of the institution, which required from society a conduct that differed from that which was being adopted.

The 1990 reform in relation to the structure of offices in the Ministry of Culture (Ministério da Cultura - MINC), caused a huge loss to the National Library, then the National Pro-Reading Foundation [1984], with the drastic reduction of at-will appointments. The number of posts fell from 249 to 84, representing a reduction of 66.3 percent in those positions.

The publication of the statute of the National Library Foundation by Decree No. 5.038 of April 7, 2004, occasioned further significant losses, with the reduction of other high level and advisory positions (Direção e Assessoramento Superior - DAS), in the areas of curatorship and special collections. 


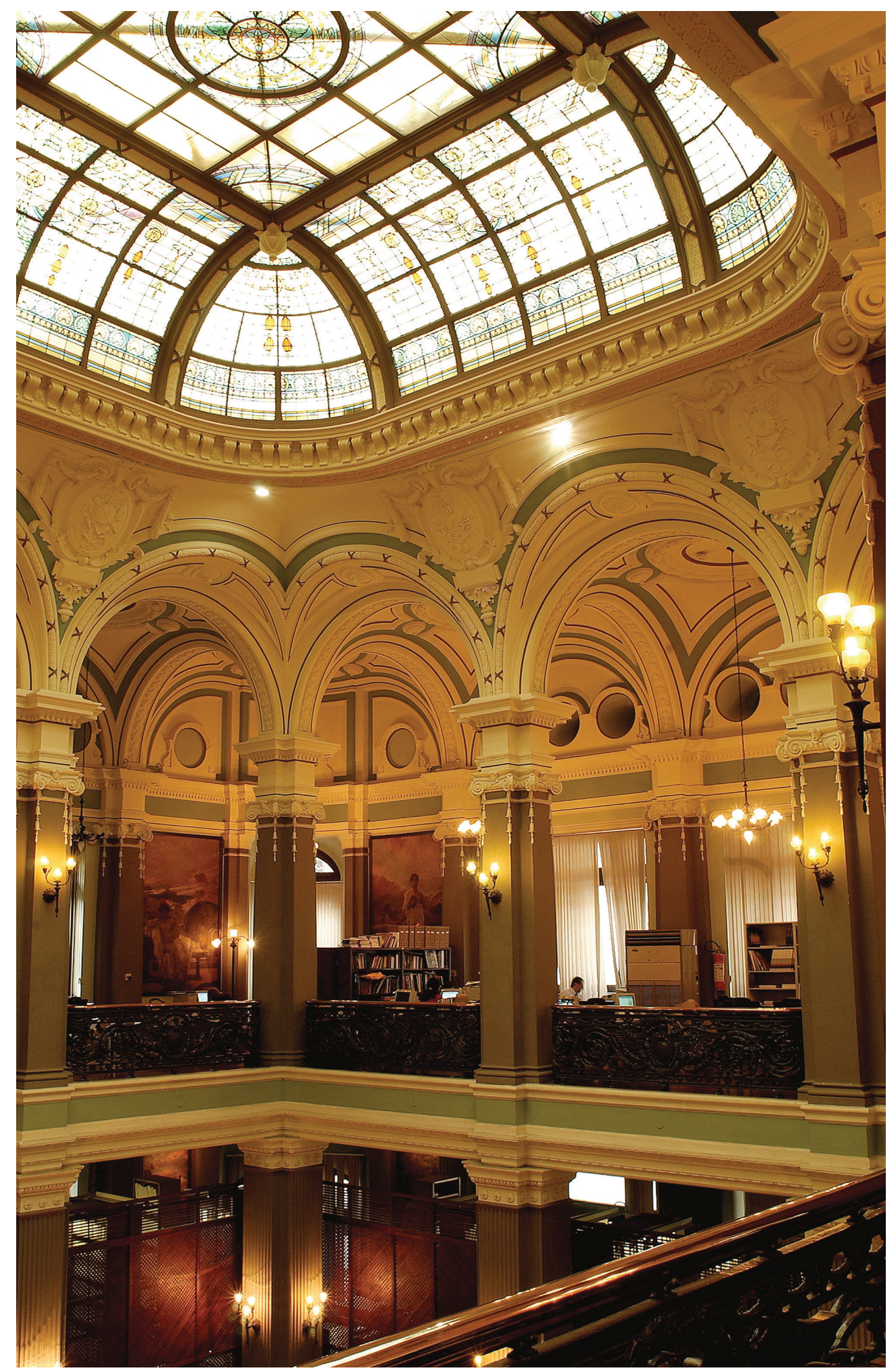

Overview of the 4th floor of the National Library building. 
Historically, strategic, National Library sectors of curatorship are responsible for the custody and permanence of the entire bibliographical and documentary memory of Brazil, which is physically distributed according to type, namely: General Works [about two million volumes, no less than six floors of warehouses, covering works published from the Eighteenth Century to the most recent ones]; Reference [consisting of approximately 70,000 items among dictionaries, general and specialized encyclopedias, atlases, guides, manuals, bibliographies, indices and other research materials]; Serial Publications [60,000 titles, which occupy about $17 \mathrm{~km}$ of shelves]; Manuscripts [800,00 documents including loose and bound items dating the from the Eleventh to the Twentieth Century ]; ${ }^{6}$ Rare Works [created on January 24, 1946 by Decree No. 20478, consisting of diverse bibliographic materials (books, pamphlets, leaflets, periodicals), with approximately 42,000 titles in 50,000 volumes, aimed at a highly specialized public]; Iconography [created in 1876, comprising the collection of foreign drawings, Italian works (Fifteenth to Eighteenth centuries) from the Royal Library, by Europeans who visited Brazil such as Debret and Rugendas, architectural designs by Landi and Grandjean de Montigny, sketches by Brazilian artists such as Pancetti and Victor Meireles, and foreign prints from various European schools (Dürer, Rembrandt and Callot among many others). One of the highlights is the Thereza Christina Maria Collection consisting of 25,000 photographs, both loose and in albums, from all over the world, by photographers such as Marc Ferrez and Reert Klumb, Nadar Roger Fenton and Muybridge]; Cartography [comprising, chronologically, collections from the fifteenth century, with a precious 1486 edition of Ptolemy's Geography, to the twenty-first century; and the Angelis collection]; Music and Sound Archive [division created by Decree No. 48108 of April 13, 1950, comprising remaining items from the Royal Library and the Music Collection that belonged to Empress Leopoldina, enriched by acquisitions and collections such as the Guerra-Peixe and Glauco Velasquez collections, and musical manuscripts by Brazilian composers such as original scores of Carlos Gomes' operas].

Coupled with the demand for at-will appointments for the areas of curatorship was the need for other management positions in various sectors, also strategic for the National Library Foundation, such as: National Plan for the Recovery of Rare Works (Plano Nacional de Recuperação de Obras Raras PLANOR); Restoration and Conservation; National Plan for the Microfilming of Brazilian Periodicals (PLANO); Digitization; Digital Library; and Cultural Production and Dissemination. The latter has endowed the institution with a new position as a democratic cultural space, transcending its scope of action as a depository library, with a prominent position on the cultural agenda of the city of Rio de Janeiro. The relevance of the programs broadcast via Embratel under the current administration, the topics presented in public seminars and debates in the field of books, reading and library, with events open to the public, espe- 
cially students and teachers, calls for a pedagogical practice that allows closer involvement with current cultural topics and with Brazilian literature, enabling dynamic educational reading activities in the classroom and in the school library.

To ensure the maintenance of its collection, the FBN has paper restoration and conservation laboratories that are able to restore, using the most modern techniques, any item in the collection. It also has a bookbinding shop and a microfilming, photography and scanning center. It acts as a center for training in conservation and restoration of bibliographic and documentary collections, offering courses, supervised traineeships and technical training through agreements, both nationally and in Latin America, in countries like Ecuador, Paraguay, Bolivia, Peru, Cuba and Mexico.

It is important to note that these areas are not included in the current statute, byt their respective duties, which have increased since 1990, are nonetheless in force within the institutional mission. Hence the the board's initiative to seek a statutory restructuring accompanied by Internal Rules that reflect the reality of the institution.

The work carried out in 2009 by the board of the National Library Foundation in partnership with directors and general coordinators and the participation of the Association of National Library Employees (Associação dos Servidores da Biblioteca Nacional-ASBN), within the limits set by the Ministry of Culture through the Strategic Management Board (Diretoria de Gestão Estratégica DGE) linked to the Executive Secretariat of the MINC, led to a proposal for statutory and regimental restructuring entitled "Institutional Strengthening Proposal", which was submitted to the Minister of Culture [August 21, 2009].

We are waiting for the decision of the Ministry of Culture on this specific matter. It would be appropriate and necessary - on the occasion of the bicentennial of the BN [2010] - to reformulate its statute to include what has been taken away from it and neglected in successive and different reforms. The institution is clearly and urgtently in need of updating and transforming its activities.

\section{The BN and public policy}

The National Library Foundation is focused on the diversified universe of the book. It seeks to be more than the national memory's security device: a place where different eras meet and, together, promote recollection, occurrence and premonition.

The bicentennial institution is in charge of reinventing, each day, that old relationship that viscerally unites books and life. The National Library Foundation is therefore the body linked to the Ministry of Culture responsible for implementing State policy in relation to books, libraries and reading, by coordinating key strategies for the interaction between these three sectors that are the very foundation of Brazilian culture.

For constitutional reasons, it is also the guardian of national memory 
and now, for technical reasons, its disseminator, making its collection available through the Internet and thus democratizing access, which today totals more than 1.15 million visits to the portal, while ensuring the preservation and durability of the works by protecting them from constant handling.

The role of the FBN can be summarized in two fronts: the first relates to the cultural memory of the organization which, as we know, is the depositary of a true treasure recognized worldwide; the second concerns the cultural life of the country, training of staff specific to the area, frequent reissuing of reference works forgotten in the dust of time, the system of co-edition with the country's editorial network, research grants, translation of works by Brazilian authors for international dissemination, support to novice writers, awards for current and new authors, the Camões Award in partnership with the Portuguese government, implementation and modernization of public and community libraries and reading centers, as well as events, such as national and international seminars and exhibitions, in addition to courses and debates to disseminate and present the diversity of offerings and the extent of reading. Thus, the first aspect relates to the book listed as heritage stored, technically preserved; and the second concerns the life of the book published both by the institution and through partnerships, which is the object of dissemination and discussion as regards its value and importance in the overall development process, which should be smoothly conducted at different economic and cultural levels.

The policy implemented by the Ministry of Culture absorbs and interprets two dimensions. On the one hand, it gathers propelling forces and energy within the social horizon, the community environment. On the other, it improves the mechanisms of dissemination and transmission. This cultural dynamic has a transformative role in social change. Culture is then perceived less as a purchase, a product and a result, and more as a creation, an action, a movement linked to social change. The "More Culture Program" implemented by MINC seeks to follow this direction. And more in this case has the dual meaning of more quantitative and more qualitative.

This is the horizon within which the new social policy of the federal government and MINC is being developed. A policy which includes among its different socio-cultural challenges - to name only what concerns the purposes of the National Library Foundation - that of maximizing the actions of cultural inclusion; of reincorporating culture as a vector of educational improvement; and of fostering the practice of reading as a determinant for citizenship, access to cultural production and the enhancement of digital culture.

All this involves, as previously mentioned, books and open-field reading and libraries. It therefore involves reputable cultural paths. And it cannot and could not relinquish the competencies of the National Library. Given the convergence of the FBN duties with initiatives announced by the "More Culture Program," it became convenient to promote an effective interaction, an inter- 
face, between MINC programs - “Open Book", a government program under the Multiyear Plan (Plano Plurianual - PPA) managed by the FBN, and "More Culture", which arose from the MINC's need to contribute to Brazilian sustainable development, so as to avoid clashes of interests, overlapped actions and a disturbing duplication of material, human and financial resources. Therefore, MINC sought in the FBN a front to implement some of its actions, to improve rationality and avoid similar and simultaneous initiatives.

The "Live Library Action" under the "More Culture Program" / MINC entails encouraging and facilitating the expansion of the activities of municipal public libraries, so that throughout the process they can become multidisciplinary or interdisciplinary cultural spaces. In this line of action, the Demo Library of Brasília (BDB), linked to the FBN, was already expanding its intense cultural and educational agenda to encourage the joy of reading by providing physical space for book releases, poetry recitals and story-telling, thus attracting other users through various projects such as the Bibliomusic, for example. With this project, the $\mathrm{BDB} / \mathrm{FBN}$ intends to demonstrate the interaction of the library with the various areas of culture, serving as a model for numerous Brazilian public libraries.

The "Live Library Action", which the National Library Foundation is responsible for implementing, is broken down into interconnected lines of action: a) Establishment and Modernization of Public Libraries, ranging from the adaptation of physical space [including electricity and telephone networks], with financial contribution from municipal governments, the donation or loan of furniture, collections [donation of books divided into categories of knowledge and age groups, including: 2,000 titles for establishment and 1,000 for modernization], microelectronic [computers and peripherals] and electrical equipment. Collections and equipment for the establishment of 1,206 public libraries have been purchased in the current administration. Throughout 2010, with the distribution of the remaining 420 , we can say that all Brazilian municipalities will have this cultural space. In the same period, properties and costing assets were acquired to upgrade 540 public libraries; b) Reading Centers, which are alternatives to the construction of libraries and cultural centers, as there are regions, districts and communities totally devoid of cultural facilities or with difficult access to existing public libraries. A total of 516 Reading Centers have already been contemplated; c) Readers Training, because it's not enough for the FBN to just offer products; it also needs to train human resources, reading agents who, acting as guides, supporters and promoters will increase the number of apprentices, support the learning process, create the conditions and the environment required for coordination of information, and demonstrate that the act of reading and writing is a way of relating the life of each individual to the reality in which they live. In this regard, Decree No. 519 of May 13, 1992 created the National Reading Incentive Program (Programa Nacional de Incentivo à 
Leitura - PROLER), linked to the National Library Foundation and hosted at Casa da Leitura (Reading House) at 56, Pereira da Silva Street, in the neighborhood of Laranjeiras, Rio de Janeiro. With regard to training, it is worth noting that this has always been a primary concern of the National Library since 1911, with the creation of the Library Science course ${ }^{7}$, which began its activities in the academic year 1915 within the National Library itself and was the first of its kind in Latin America and third in the world. And so the FBN keeps on contributing to build a country of readers and therefore of citizens.

Both implementation and modernization actions have already been carried out for some time by the National Library Foundation under the "Open Book Program" through the General Coordination of the National Public Library System (Sistema Nacional de Bibliotecas Públicas - SNBP) established by Decree No. 520 of May 13, 1992, with the main objective of strengthening these libraries and establishing a dialogue with the regional coordinating units and municipal governments, thus keeping the management of all activities within these two areas. The General Coordination of Planning and Management (CoordenaçãoGeral de Planejamento e Administração - CGPA) is responsible for implementing acquisitions and distributions, with a view to achieving the proposed goals. Currently the FBN acts as the operational arm, and the Ministry of Culture is responsible for making political decisions. Thus, the Foundation works in partnership with the Book, Reading and Literature board of MINC.

As legal depository of the bibliographic heritage of Brazil since 1907, the FBN is responsible for the formulation of public policies to safeguard the national language and culture, thus ensuring future generations, access to the intellectual production embodied in the various forms of knowledge registries that make up the memory of Brazil. Providing the public with these collections is within the spirit of guaranteeing access to the country's bibliographic and documentary heritage. The institution has thus been supporting both the strengthening of these actions through the preservation and dissemination of this collection both locally and remotely, and the generation of digital contents that democratize, nationalize and internationalize accessibility to knowledge and information. The FBN contributes to the processes of social and digital inclusion, thereby complementing formal education.

The National Digital Library (http://bndigital.bn.br/) was established in 2007 with a view to consolidating the integration of the National Library into programs of access to cultural assets. Conceived mainly as an environment that houses all digitized collections, it promotes access to national and international projects developed in partnership with several institutions such as the U.S. Library of Congress, the Getty Foundation and the Brazilian Federal Savings Bank. A total of 30,00 items have already been scanned, but much work remains to be done due to insufficient technological and human resources, requiring extra-budgetary support. On the internet one can find rarities like the photo- 
graphic collection of the emperor D. Pedro II and documents about slavery and the Paraguay War, which are examples of free accessibility to public collections.

In relation to international projects, the $\mathrm{FBN}$ is one of the founding partners of the World Digital Library, a program developed by the U.S. Library of Congress and UNESCO for the purpose of promoting knowledge both internationally and cross-culturally and increasing the amount and variety of contents on the Internet, so as to provide informational resources for teaching staff, researchers and the general public, in addition to training affiliated institutions with the aim to reduce the digital divide within and between countries. The World Digital Library celebrates its first anniversary with the following statistics: pages visited $[67,050,896]$; visitors $[9,415,444]$, with Brazil ranking fourth among the countries visited; as regards the language of the pages visited, Brazilian Portuguese ranks third with 10.1 percent, after Spanish [51.5 percent] and English [22.9 percent]; among the most visited items are the Map of Spain and Portugal and Thereza Christina Maria, Empress and D. Pedro II's wife. Both documents belong to the National Library. ${ }^{8}$

The FBN has maintained the Electronic Library Consortium active and growing. Launched in 1999, it brings together Brazilian Libraries in an exchange network, enabling facilities and training its components in pursuit of a level of modernity. Currently 48 university libraries and 33 public libraries (nonuniversity) linked to the National System of Public Libraries (Sistema Nacional de Bibliotecas Públicas - SNBP) participate in the Consortium.

The FBN also manages the project Network of Brazilian Virtual Memory (Rede da Memória Virtual Brasileira-RMVB) developed in partnership with FINEP-MCT, in order to support automation and to put the collections of participating libraries online, thus inventorying and disseminating the Brazilian memory stored in different collections across the country; the creation and generation of digital unpublished contents of relevance to regional and national culture; their dissemination through the website of the Network of Brazilian Virtual Memory/FBN, allowing universal access to the Brazilian cultural diversity and contributing to the implementation of digitization policies and the creation of a Digital Repository of National Memory. It also aims to expand the Network portal, thus enhancing its digital content and the number of partnerships by offering a system database and hosting of metadata and digital files to partner institutions responsible for maintaining collections and knowledge production.

The FBN also issues opinion on cultural projects submitted to MINC under the National Program for Cultural Support Cultural (Programa Nacional de Apois Cultural - PRONAC), on topics related to books, reading and literature, including reference works.

Engaged in the policy of access to cultural production, it works actively in the distribution of publications from the National Library Foundation and the Rouanet Law (Patronage). Recipients include: libraries linked to the National 
System of Public Libraries; federal, sate and municipal university libraries; libraries of Geographic and Historical Institutes; popular municipal libraries; labor court libraries; libraries managed by the FBN; and national and international book fairs promoted by the institution and in which it participates. Books are sent also to the Iberian-American National Libraries [22 libraries that are part of the Association of Iberian-American States for the development of the National Libraries of Iberian-America (ABINIA), as well as to international organizations with which the FBN maintains links: Spanish Agency for International Cooperation (AECI), Organization of American States (OAS), Latin American and Caribbean Economic System (SELA), Adrés Bello Agreement (CAB), United Nations Development Program (UNDP)]. The distribution can be summarized in three lines: duplicates of the FBN collection, works of the institution itself and Brazilian official publications. This distribution role [Decree No. 20529 of 1931] comprises national and foreign institutions, and includes monographs, special material and serials. With these actions, the FBN is part of the policy for the publication and distribution of diverse books.

Throughout the Twentieth Century, as can be seen, the National Library has diversified and improved its activities. The new roles currently played by the FBN include representing the International Standard Book Number (ISBN) and the International Standard Music Number (ISMN) in Brazil.

\section{Action strategies}

To perform its tasks, the FBN develops procedures associated with thirty actions distributed through seven programs under the Federal Government Multiyear Plan (PPA), of which two relate to its end-area: Brazil Cultural Heritage and Open Book.

Despite budget, technical and human resources shortfalls ${ }^{9}$ relative to new demands, we dare to conclude that the National Library Foundation has carried out its functions with broadly satisfactory results, aiming to become a special high-tech instrument both nationally and internationally in the book area and in the logistics arm of the actions of the Live Library under the Ministry of Culture's More Culture Program.

With regard to its action strategies, the FBN has avoided a Manichean and perhaps even a nostalgic approach, which would have isolated printed culture from oral and electronic culture (communication), here symbolized by the Accessible Library. It is about building bridges, connections, interfaces between virtual communication and written culture, aware that the two, working in close coordination, can create extremely promising spaces for construction and reconstruction. Therefore, it is advisable to generate an intercommunicative space, without voiding any of the two levels that feed on the mutual energy they provide one another. The National Library Foundation has been seeking to socialize information and, to this end, it harmonizes actions developed under the Cultural Heritage Program - preservation of cultural collections, in which 
it incorporates activities related to conservation, cleaning and restoration and microfilming procedures - actions under the "Open Book Program" - customer service, both personally and remotely, in which the highlights are the National Digital Library, the Electronic Library Consortium managed by the FBN, online catalogues, expansion of bibliographic and documentary collections, and enhancement of the institutional portal (www.bn.br).

It can be concluded that in the context of modernity the actions of the National Library Foundation have multiplied substantially, with particular attention to quality, covering a very broad spectrum in which event-related initiatives can be easily identified: exhibitions, roundtables, debates. Events that take place at the FBN headquarters are being broadcast nationally via the Embratel Program. ${ }^{21}$ In this perspective, the library crosses the limits of its physical space and dialogues with society, thus contributing to the development of individuals and to the necessary consistency of a critical spirit. Transcending national borders, it is also present in international fairs, bringing exhibitions on important national facts, documentaries on the FBN, thereby disseminating Brazilian culture also through publications.

A means for the analysis of memory, a space for the conservation of intellectual, artistic and literary heritage, the library is a place for dialogue with the past, but also for creation and innovation. It is a place, an institution. It is the paradoxical intersection of a healthily utopian project (all the traits of human thinking entrusted to writing coexisting in the same place), of technical and ergonomic constraints, and of policies for the conservation, selection, classification and communication of texts, images and currently of sounds as well. It is also, and simultaneously, an intellectual design, a project, an immaterial concept that gives meaning and depth to the practices of reading, writing and interpretation. The $\mathrm{BN}$ is finally a collection of books, the resulting effect of its juxtaposition and interaction. A library is not necessarily just an establishment, as we learn from the radiations of Alexandria or computer servers that currently transmit from a distance scanned books and articles.

For its architecture, the definition of its audience, the principles that rule its collections, the technological options that determine the accessibility to and materiality of texts, as well for the visibility of the intellectual choices that organize the classification, every library conceals an implicit and explicit conception of culture, knowledge and memory, as well as its role in the society of its time.

The history of libraries in the West is inseparable from the history of culture and thought, not only as a place of recollections containing the lessons of the inscriptions left by previous generations, but also a dialectical space where, at each stage of history, the limits and functions of tradition, the boundaries of the utterable, the legible and the thinkable, the continuity of genealogies and schools, the cumulative nature of the fields of knowledge or its internal fractures and reconstructions are negotiated. 
At the crossroads of the history of books and libraries, a new approach to cultural practices was developed some years ago, attentive to the sociology of the intelligentsia, the techniques of writing, the set of gestures, the working places and models of thought as dynamics of knowledge tradition and memory. The power of libraries lies in the convergence of these different paths.

The power of libraries does not rest in the world of words and concepts alone. The domain of the written archive and the accumulation of books are not without political meanings. They are signs and instruments of power; spiritual power of the Church; temporal power of monarchs, princes, aristocrats, the nation and the Republic; economic power of those who have the necessary means to buy books, either printed or manuscripts, in large numbers; intellectual power and power over the intellectuals.

For all that, the National Library is a citizen library, designed to inform, educate and implement free choice conditions. It thereby fosters the formative role of reading. It is the readers, the users and society at large that confer legitimacy and results to the work of the institution. Likewise, the intellectual and scientific community, by receiving and transmitting the new requirements of research and new information technologies with the National Library Foundation as an ally, has been guiding the bicentennial institution towards what is being called "library without borders".

The FBN recognizes that without renewal or innovation, the National Library would lose all its fascination and its goals of developing and disseminating information, transmitting its multidisciplinary collection, heir of the Royal Library and permanently updated. It is thus a privileged space of knowledge. That is why it houses, justifies and encourages, among its actions, the promotion of diversified cultural actions in Brazil and abroad, with the proposal of democratizing culture, education and Brazilian society.

The National Library Foundation is, however, aware that actions aimed at transformations cannot be conducted by an isolated individual and from top to bottom. The psychosocial processes and the process of individual-group-society interaction are particularly entwined here. It is not enough to go from still latent aspirations [of higher levels] to conscious aspirations [federal, state and municipal level]. With regard to the establishment and modernization of public libraries, the municipalities should voice their priorities, turn them into claims so that they can prevail in the decision. And this process is still incomplete. Awareness and the expression of current needs only result in corporate claims in everyday space. It is from this awareness of the genesis and transformation, of the possible role of aspirations, interests, needs for these changes, the broad absorption of contradictions and conflicts between the central government [MINC/FBN] and decentralized power [individuals, communities, municipalities] that a true social project can materialize. Only the understanding of the processes in which the actors are involved allows them to prepare a joint document, make predic- 
tions, lead an effective action. Therefore, the changes through culture are still under construction, but the path has already been paved and is being increasingly expanded.

The National Library has been developing instruments to meet the challenges of the present and prepare for future achievements. There may be some utopia in this form of prospecting, but it will definitely be a "concrete utopia", rooted on the ground or in the water, of what was once a privileged space in the City of São Sebastião do Rio de Janeiro, which is still at the forefront of the construction of a fundamental instrument for the development of the country.

\section{Notes}

1 This law, presented by Medeiros e Albuquerque, its namesake, assigned to the National Library the duty of registering literary, artistic and scientific works [printed, photographed, lithographed or engraved works]. Both Law No. 496 and the instructions of June 11, 1901 are reproduced in the Annals, v.33 p.357-61, 1911.

2 About the collections, acquisitions, and enrichment of the collection, see the publications of experts such as Schwarcz (2002), Carvalho (1994) and Herkenhoff (1996).

3 Although the beginning of the press in Brazil officially dates to 1808, this paper proves that this activity had been previously carried out.

4 The first public library was established in South Caroline, in the year 1700, leading to the first library protection law. This system spread throughout the U.S. and its example was followed in Europe, New Zealand and in the rest of the world. On the various types of libraries see Carvalho (1994, p.15-28).

5 Information obtained on the FBN website at <www.bn.br>.

6 The manuscripts of the Royal Library were added to the documents collected by the State Secretary of Imperial Affairs or Ministry of the Empire. It is an indispensable reference for researchers in history and literature, gathering manuscripts in Greek, Latin, Persian, ancient, classic and contemporary Portuguese, and with the most different types of writing, language, and paper.

7 See Carvalho (1994, p.85).

8 Data provided by Michelle Rago, director of the Technical Project for the World Digital Library, US Library of Congress, on April 22, 2010, who was responsible for managing the Project.

9 The number of places for the public entrance examination held in 2006 was insufficient to meet FBN needs. Add to that the loss of civil servants who moved to other federal, state and even municipal institutions offering better pay. 


\section{References}

ANNAES DA BIBLIOTHECA NACIONAL. Rio de Janeiro, v. XI, p.457, 1883 1884. CARVALHO, G. V. de. Biografia da Biblioteca Nacional (1807 a 1990). Rio de Janeiro: Irradiação Cultural, 1994.

CUNHA, L. da F. F. da. Subsídios para a história da Biblioteca Nacional. Anais da Biblioteca Nacional, Rio de Janeiro, v.101, p.123-46, 1981.

HERKENHOFF, P. Biblioteca Nacional: A história de uma Coleção. Rio de Janeiro: Salamandra, 1996. [2.ed. Sextante, 1997].

SCHWARCZ, L. M. A longa viagem da biblioteca dos reis: do terremoto de Lisboa à independência do Brasil. São Paulo: Cia. das Letras, 2002.

ABSTRACT - History and Memory of the National library. The concept of public and national library. Integration between physical and digital library. Reading and citizenship. Transparency. Accessibility. A new conception of the National Library Foundation, based upon a unitary structure of time, which holds past present and future, from a retrospective, perspective and prospective approach. Lesson and Life of the National Library Foundation.

KEYWORDS: Library, Normalization, Reading, Changes, Computerization.

Célia Maria Portella holds a degree in Pedagogy, a Master's Degree in Education and a $\mathrm{PhD}$ in Communication and Culture from the Federal University of Rio de Janeiro (UFRJ). Since December 2005 she has been executive-director of the National Library Foundation, at the invitation of president Muniz Sodré. @ - celiamportella@ gmail.com

Received on 18 May 2010 and accepted on 24 May 2010. 